\title{
The Scientific Articles on Art Criticism
}

\author{
Mina Hedayat ${ }^{1}$, Pegah Jahangiri ${ }^{1}$, Aida Torkamani ${ }^{1}$, Mahsa Mashayekhi ${ }^{2}$, Sabzali M. K. ${ }^{3}$ \& Nader Ale Ebrahim ${ }^{4}$ \\ ${ }^{1}$ Cultural Center, University of Malaya, Kuala Lumpur, Malaysia \\ ${ }^{2}$ University of Applied Science and Technology, Art and Culture Branch 23, Malaysia \\ ${ }^{3}$ Academy of Malay study, University of Malaya, Kuala Lumpur, Malaysia \\ ${ }^{4}$ Research Support Unit, Centre of Research Services, Institute of Research Management and Monitoring (IPPP), \\ University of Malaya, Malaysia \\ Correspondence: Mina Hedayat, Cultural Center, University of Malaya, 50603 Kuala Lumpur, Malaysia. Tel: \\ 60-145-0518-5033. E-mail: zemestonbahar@yahoo.com
}

Received: November 28, 2014 Accepted: March 16, 2015 Online Published: May 16, 2015

doi:10.5539/ass.v11n13p130 URL: http://dx.doi.org/10.5539/ass.v11n13p130

\begin{abstract}
Research has been extremely involved in improving in the art criticism area. These improvements are reflected in scientific articles. This article purposed to investigate the 214 articles in art criticism to explore their main characteristics. These articles published in the Web of Science database of the Institute of Scientific Information (ISI) from the period of 1980 till 20 December 2013. Types of articles were article and review which is included in the study. The three top cited (more than 10 times citations) articles in art criticism were published in 1993 and 1999. The 214 articles mean citation rate was 0.87 (SD 2.38) times. Among the various fields, art (58.87\%), arts humanities other topics (28.03\%), both art and arts humanities other topics (5.14\%), both art and education and educational research $(2.33 \%)$, both art and history $(1.40 \%)$, art, arts humanities other topics and literature $(1.40 \%)$, both art and cultural studies $(0.93 \%)$, both art and philosophy $(0.93 \%)$, both art and literature $(0.46 \%)$, and both arts humanities other topics and cultural studies $(0.46 \%)$ were the most popular fields of research. The results showed that researches were done in the United States had highest citation which was written in English language.
\end{abstract}

Keywords: citation-classics, art criticism, journal, association, article

\section{Introduction}

In the sixteen century scholars collected and produce information on philosophical doctrine and critical approaches (Cromer, 1990). Lankford (1984) stated that achieve knowledge in art criticism may also benefit one encounter other skills principal to life. Art criticism elevates appreciation of art and the procedure of critical thinking. Lankford (1984) stresses on the observer's awareness, in addition to the attributes of the artwork. Risatti (1987) believes that involving art criticism may assistance learners to improve critical thinking skills and problem-solving skills. It makes them to read about, think about, and discuss the values of society; then has them analyzed such values against the backdrop of the social order, as well as question their role in society because contemporary art and historical art both reflects and a construct those values. Art criticism around the world is in crisis. Art criticism has a poor voice, and become solve into the antecedent irregularity of glancing cultural criticism. Nonetheless its decline is not the usual ultimate weakness pressure of a workout that has continue its period, because at the similar period, art criticism is as well as better than forever (Elkins \& Engelke, 2003).

Since 1975, the Arts \& Humanities Citation Index (A \& HCI) has been accessible, and from 2004 researchers been allowed to review the arts and humanities bibliometrically through Scopus and Google Scholar as replacement (Leydesdorff \& Salah, 2010). In scientific articles especially within the most cited ones these progressions are reflected. Therefore, only a small part of the literatures published in these fields covered by the analysis of the journals coated by the A \& HCI (Leydesdorff, Hammarfelt, \& Salah, 2011).

The requirement to take up with the quantitative techniques to study scientific literature resulted in the progress of Bibliometrics and its index. Bibliometric markers, which are just article-based, are less illustrative of social and humanities research than natural sciences ( Nederhof, Zwaan, De Bruin, \& Dekker, 1989) We utilized these tools to see the key works within the art criticism studies in this research. AHCI and SSCI constitute only $23 \%$ of 
the content of Thomson Scientific databases contrary to the natural sciences that represents $77 \%$ (Jacso, 2005).

Based on our knowledge this article is the first study that has reported the articles in the field of the art criticism. Though, no exhaustive article has dealt with articles in art criticism. This research is an endeavor to distinguish the 214 articles related to art criticism to help art critics and scholars verify the areas of study in art criticism that have been broadly addressed along with the gaps that ought to be focused.

\section{Methods}

Because this study only proposed to look for articles related to art criticism and relevant subjects, the exploration for all relevant articles to "art criticism" was managed by ISI Web of Knowledge database. Art \& Humanities Citation Index (A \& HCI) was selected as the citation database. However, the A \& HCI the fundamental database being used for these ranking has insufficient coverage of the humanities (Leydesdorff et al., 2011). The following keywords were used to find articles: art criticism and criticize arts. Art criticism articles were filtered to exclude from the search findings. Proceedings, editorials, and letters were retrieved. The articles were inputted into an excel spreadsheet based on their citation times.

Various articles were cited more than the rest as a result of the time difference since publication. For each article the citation index was also regulated to supervise and control this particular error. The citation index was described as the mean number of citation times per year (Ale Ebrahim et al., 2013; Loonen, Hage, \& Kon, 2008). Then the cited articles were classified based on the number of citations and value of citation index. The noticeable discrepancy within the citation accomplishment of researchers in the arts and humanities may be considered disadvantage for applied citation analysis. Citation exercises are not decently perceived in the arts and humanities; humanities researchers' dependence on differing media, which can be covered by the scholarly databases (Ale Ebrahim, 2014; Leydesdorff \& Salah, 2010).

The articles were categorized based on the article details, like date of publication, name of journal, organization, title, authors' names, and country. Method of data collection in this study was classified as a retrospective, prospective, longitudinal, and cross-sectional. The research design was outline to be qualitative also (Portney \& Watkins, 1993). We categorized the articles based on art criticism, such as art and humanities multidisciplinary. The articles were classified into different fields of art, arts humanities other topics and education educational research.

Statistical analysis was accomplished utilizing SPSS 18 (SPSS Inc., Chicago IL). Nonparametric test of Kruskal Wallis was employed for comparison and contrast the differences with an alpha level of .05. Descriptive statistical analysis was evaluated as counts or percentages of parameters.

\section{Results}

\subsection{Sources and Citations}
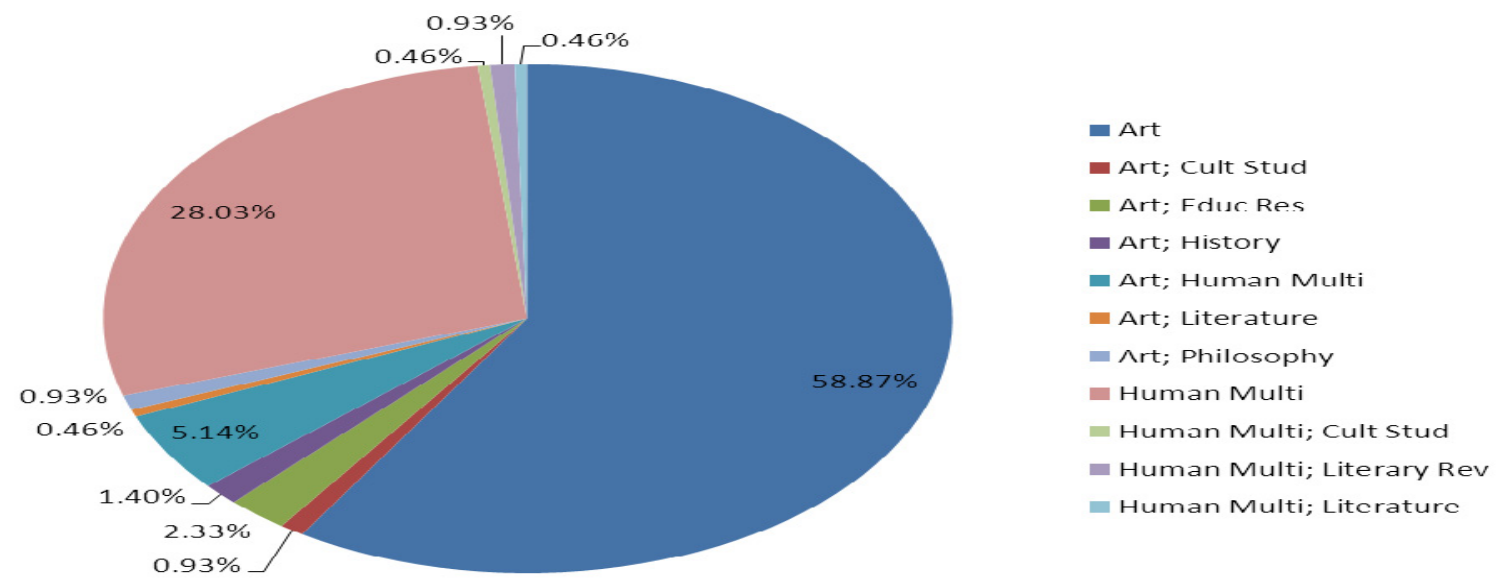

Figure 1. Different categories of the 214 articles in art criticism 
Two hundred fourteen published articles were selected from 1980 to 2013 with a citation range of 0 to 21 times since publication time. The mediocre citation rate was 0.87 (SD 2.38) times. The citation number was utilized to categorize the articles. The results showed that Art Criticism published 21 articles following by Journal of Aesthetic Education (16 articles), Artforum (13 articles), and Art Magazine (10 articles). The rest journals published less than 10 articles.

The highest number of citations, 21, was related to an article on art criticism that was published in 1993. Number of published articles from 1980s was more in comparison with 1990s and 2000s ( 85 vs. 75 vs. 44). Off all the articles, $66.66 \%$, and $33.33 \%$ were published in the Web of Science category of art and humanities multidisciplinary, respectively, with each category found alone or in combination in the following published articles percentages: art (68.87\%), humanities multidisciplinary $(28.03 \%)$, art and humanities multidisciplinary (5.14\%), art and education educational research (2.33\%), art and cultural studies, art and philosophy, humanities, multidisciplinary and literary reviews $(0.93 \%$ each), art and art history, art and literature, humanities multidisciplinary and cultural studies, and finally humanities multidisciplinary and literature $(0.46 \%$ each $)$ (Figure 1).

\subsection{Study Field and Journal Distribution}

Among the 214 articles, the greatest number was on art (126 articles), followed by $28.03 \%$ and $5.14 \%$ of the articles addressed arts humanities other topics and both art and arts humanities other topics, respectively (Figure 2).
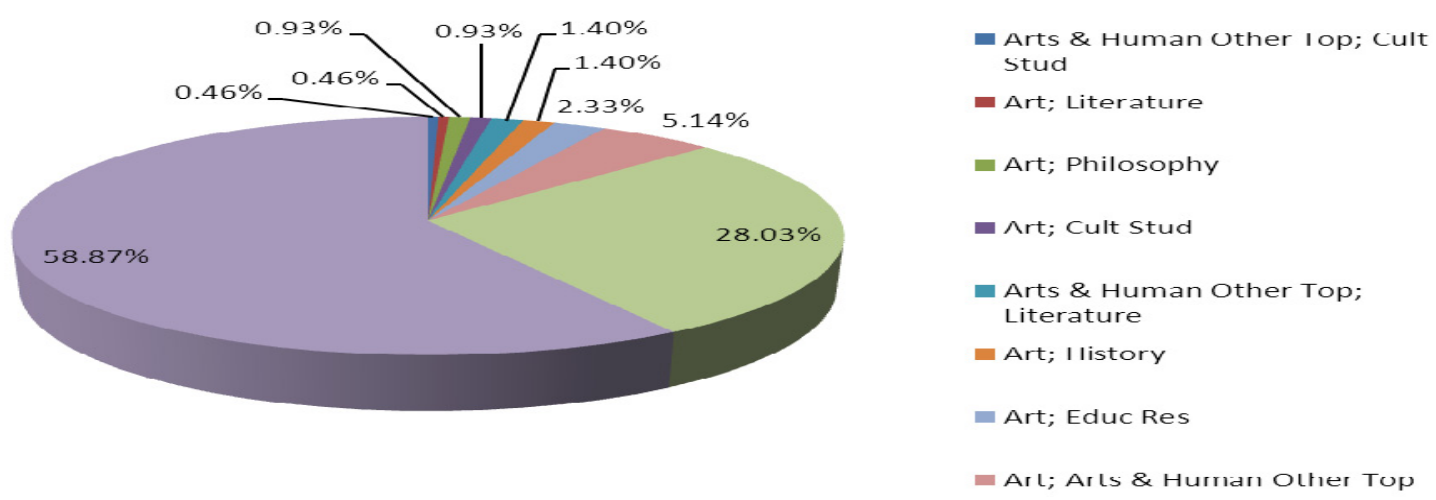

Figure 2. Different fields of the 214 articles in art criticism

Most of the top cited articles $(5 \leq$ citation times) from the United States focused on the art ( 3 articles), art humanities other topics ( 1 article), and both art and arts humanities other topics ( 3 articles). This rate was two (art) for United Kingdom.

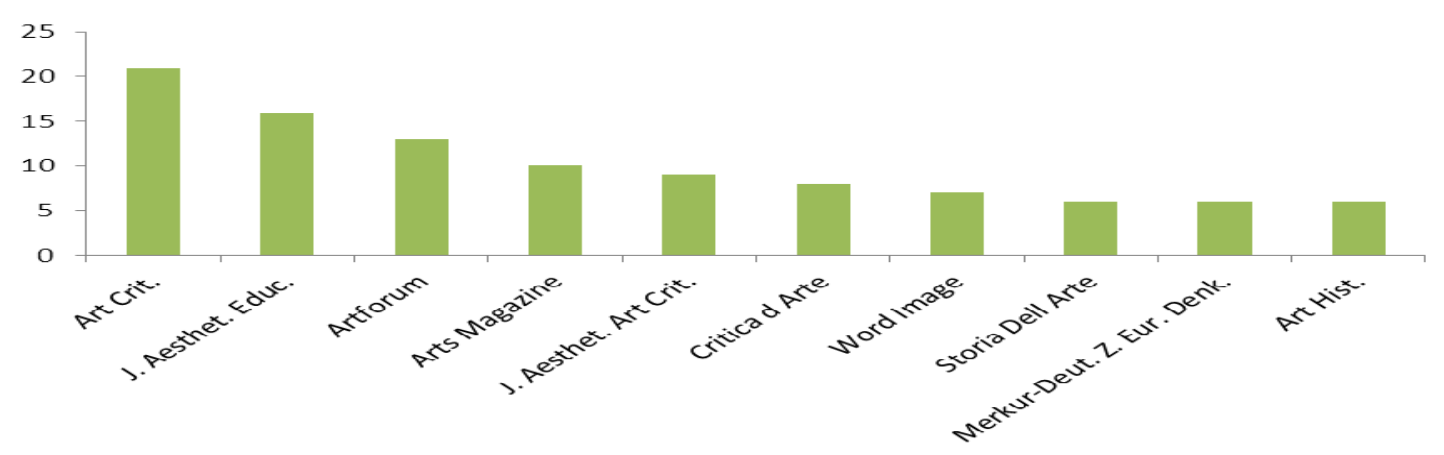

Figure 3. The top 10 journals that published the topmost number of the 214 articles

Five premier journals with the topmost number of the articles citation: 1) Art Criticism (9.81\%); 2) Journal of Aesthetic Education (7.47\%); 3) Artfroum (6.01\%); 4) Art Magazine (4.67\%); and 5) Journal of Aesthetics and Art Criticism (4.20\%) (Figure 3). In total, the 214 articles obtained 186 citations, from which Journal of 
Aesthetics and Art Criticism with 21, 15, and 13 times were the topmost number of citations. A critical discrepancy was noticed among journals regarding to citation $(P=0.000)$ in the 11 top-cited $(5 \leq$ citation times $)$ published articles.

\subsection{Authors, Organization and Countries of Origin}

The 214 articles were produced by 231 writers. The mean number of authors per article was 1.0 (SD 0.53 ). Although majority of the articles had one author $(n=204)$, two and one articles had two and three authors, respectively. The highest number of authors was eight (one article). The most repeated first author of the articles was D. B. Kuspit, G. Geahigan, D. Carrier, and P. Halasz $(n=3)$. Stony Brook University leaded the most with five published articles.

Most of the articles origins were from the United States (30.37\%), United Kingdom (7\%), Germany (4.20\%), and France (3.73\%). Figure 4 shows the distributed articles between the countries of origin. Among the 11 top cited articles $(5 \leq$ citation times), nine and two articles belonged to United States and United Kingdom, respectively. The articles from the United States attained 90 citations in total, while the articles from the United Kingdom had 10 citations only.
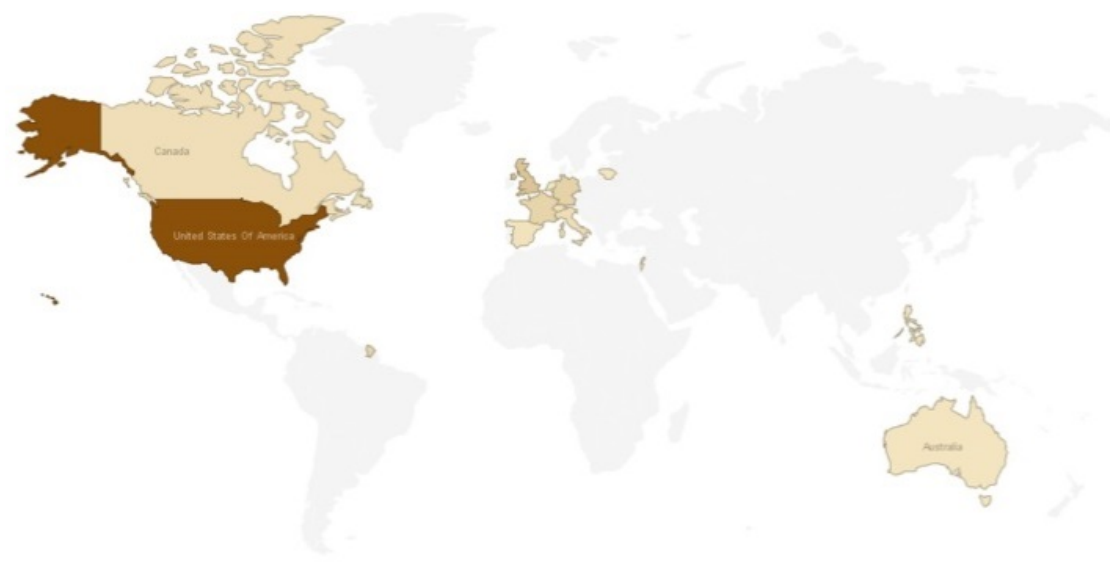

Figure 4. The percentage of the articles in the countries of origin

\subsection{Language}

Sixty eight percent $(68 \%)$ of the articles were published in English language, after that Italian language with $9.80 \%$ and French by $8.88 \%$ were the most language which used for writing the articles (Figure 5).

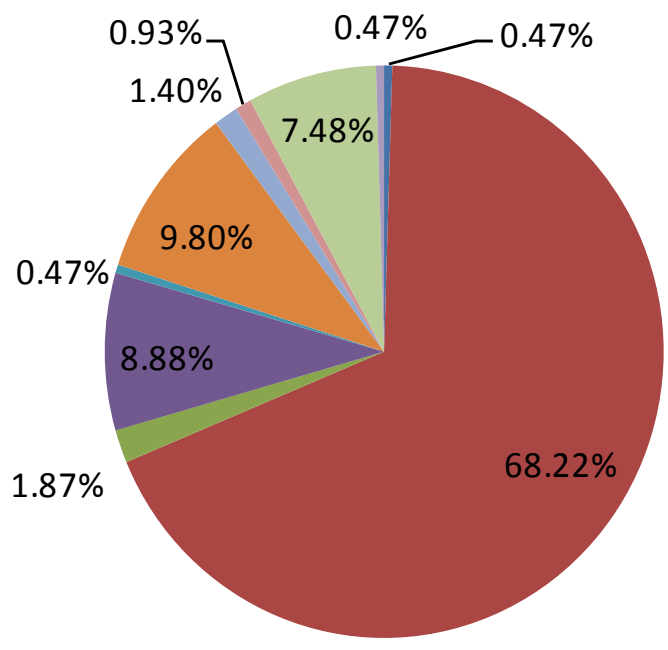

French; English

English

Spanish

- French

Dutch

- Italian

- Lithuanian

Portuguese

German

Figure 5. The percentage of the articles in different languages 


\subsection{Number of Publication}

In the 1980s the number of publication in art criticism was 85 , while in the $1990 \mathrm{~s}, 2000 \mathrm{~s}$, and $2010 \mathrm{~s}$ were 75,44 , and 10, respectively (Figure 6). This result showed that there is a decrease in publishing art criticism articles from 1980 till present.

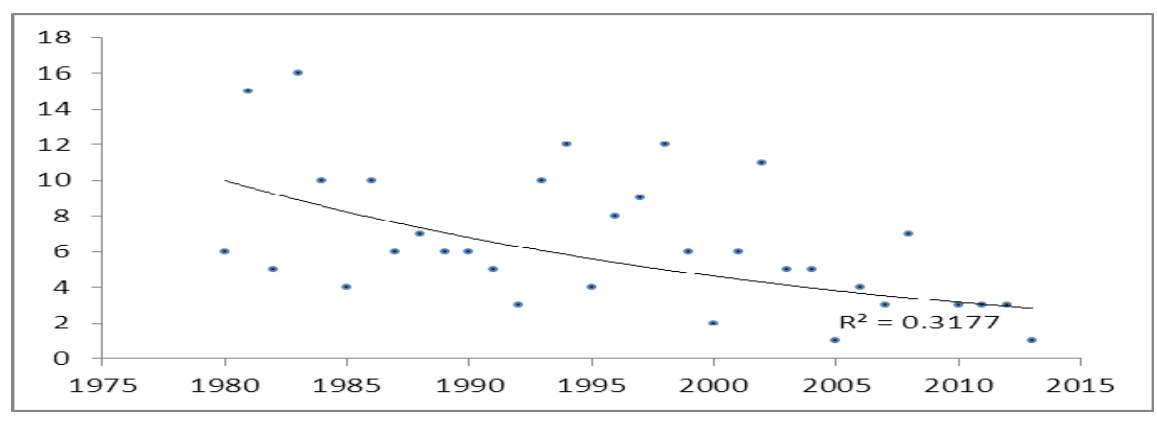

Figure 6. The number of publications was published from 1980-2013

\section{Discussion}

The field of art criticism accustomed to discuss about art and writing critical judgment. Usually, in every field of study, a number of research papers impact significantly on the advancement of a given discipline on account of providing the support for methods, improved process, or new ideas. The most significant articles were acquired through the citation number (the count of citation times for articles) (Ponce \& Lozano, 2010). The present research, supported by the systematic citation analysis, intended to classify articles that have prompted the art criticism. Although art criticism could be divided into three categories including philosophy, literature and art humanities, art humanities was chosen in this study because it is related to art. One of the acknowledged standards to measure a journal's importance among the equivalent study is the journal impact factor (Garfield, 2006). In this research, the journals were obtained from different field, and the larger part of journals were from the art field, pursued by arts humanities other topics, arts humanities multidisciplinary, and education educational research.

Majority of the articles (97.20\%) were original articles and 2.80\% were reviews; however we had expectation of a higher number of review. None of the articles were review articles in the 11 top cited journals, whereas all of which contained the genuine articles. Results are in distinction with common assumption that the review articles have the topmost citation number (Ale Ebrahim et al., 2014; Dubin, Hafner, \& Arndt, 1993). The findings of this study are coherent with former research on the topmost cited articles in different field (Baltussen \& Kindler, 2004). The results perhaps are related to the preference for citing the experimental evidence rather than review articles or expert opinion. In the A \& HCI, actually books, chapters, and other types of writings justify for most (>70\%) of the output of the humanities (Leydesdorff et al., 2011).

However, document types (e.g., books, monographs, book review, etc.) other than journal articles must be considered as significant ways of exchanging information in the humanities (Garfield, 1982; Hicks \& Wang, 2009; Nederhof, Zwaan, De Bruin, \& Dekker, 1989). Social sciences and arts and humanities research articles, both are the very common kind of writings, trailed by books for arts and humanities and by abstracts for social sciences (Nwagwu \& Egbon, 2011). In the social sciences comparing to the natural sciences, approximately four times as many books and one third as many journals were cited which show us that more info assets are created than indexed resources used in the databases of the research study (Earle \& Vickery, 1969).

On the citation of the papers in previous study which was done in Nigeria, social science papers collected exceedingly higher number of citations compare to the arts and humanities papers, as would be predictable (Nwagwu \& Egbon, 2011). The social science publications have higher citations than the arts and humanities as generally the prior appertain to local research, whereas art humanities commonly deal with people's cultural and traditional issues.

Social science and humanities' fields have additional paradigms challenging each other, causing disintegration in social science and humanities literature. This trait prevents the development of a steady "core" of scientific journals, alike that article-based bibliometric analysis in the research is hard to supervise effectively (Hicks, 1999). 
Although the articles were published between 1980 and 2013, the eighteen years duration of 1981 to 1999 had the most topmost number of top cited articles. Eight chronological flow of the top cited papers is in accordance with former results, and the findings signify that the highest acknowledgment of significant articles in a field can be gained in span of 10 to 20 years period (Albert, 1988).

Out of 214 articles, only two articles were from Asian countries and no the top cited articles originated from Asia (Pikić, Mayer, \& Macan, 2012) and the highest number of the articles came from the United States. These findings are in accordance with former studies and are in line with the reported significant impact of the United States in different fields (Hall, 1998; Hennessey, Afshar, \& MacNeily, 2009; Loonen et al., 2008; Paladugu, Schein, Gardezi, \& Wise, 2002).

Moreover, authors originated from the United States generally favor to publish in American journals and more probable to cite other American articles (Dumont, 1989). No relationship between country and citation $(P=$ $0.230)$ and field and citation $(P=0.298)$ was examined, which signifies that an article does not inevitably originate from a specific country or field to turn into the top cited article. In addition, the highest depicted country in AH journals is Croatia in $67.5 \%$ articles $(n=569)$ somewhat one of the writers originates from Croatia during 2008-2010. After Croatia, the single most represented countries in AH journals are the United States $(n=45 ; 5.3 \%)$ and Serbia $(n=29 ; 3.4 \%)$ (Pikić et al., 2012).

The subject of published articles in a journal reflects both the inclination of the board of editorial and the authors' concern. Though, the article citation rate indicates its impact on the readers. As a result, articles addressing art were more relevant than articles addressing the arts humanities other topics, art humanities multidisciplinary and education educational research. The current study also examined the hypothesis that several countries might have worked more on art criticism. Additionally, could be proven that articles in art criticism with concentration on art could achieve a higher citation.

All the 11 top cited original research articles had a qualitative research design. The findings might indicate that quantitative studies in art criticism are required. So there is a gap to investigate about art criticism and implementing criticism theory for different level of study and variety field in art.

About $68 \%$ of the articles were published in English; this result is in contrast with previous study in Croatian (Pikić et al., 2012). They stated that $65 \%$ of papers in SSO (Social Science and Other) and AH (Art and Humanities) journals have been written in Croatian, though just $3^{\text {rd }}$ paper was written in some foreign language; moreover all papers were published in Croatian. A subject in the humanities or social sciences can be advanced in a particular language (e.g., French) and therefore improve a semantics that is grounded in this language (Archambault, Vignola-Gagne, Côté, Larivi? re, \& Gingrasb, 2006). Although social science and humanities study themes are occasionally local in adjustment and, as an outcome; the goal is frequently restricted to a country or region (Glänzel, 1996; Hicks, 1999; Nederhof et al., 1989; Webster, 1998; Winclawska, 1996). This is also a reason that social science and humanities researchers publish more frequently in their native languages and in journals with a bounded repartition (Line, 1999).

Moreover, the results of this study showed number of publications that were published from 1980-2013 has decreased. Our results are consistent with previous study by Nwagwu and Egbon (2011). Since 2002 citation of the social science papers has developed constantly, however, the finding demonstrates that producing paper in arts and humanities and social sciences has truly been decreased since 2004.

\section{Limitations of the Study}

We identify some probable methodological limitations in this study. First of all, the journals attitude toward acceptance or rejection of a submitted manuscript is not similar. Accordingly, the applicability or quality of publications in specific journals might have affected by their stricter choice standards. The criteria might be an explanation why the topmost cited articles were published in one journal

Second, citation counts might arise problems and challenges, like discounting possible citations in books, self-citations, papers' priority to cite articles of the journal they submit their work, and priority of review articles or full-length articles to be cited. The citation number best identifies work value and is an excellent standard of an writer's influence and research originally compared with article number (Bohannon \& Roberts, 1991). Next, chronological bias is possible in the current citation analysis on account of former articles can be cited more often regardless of factual influence; while more lately published articles had inadequate time to obtain high citation rates. As a result, recently published articles might have been undervalue in relation to their influence (Bohannon \& Roberts, 1991). Accordingly, the probability of unfairness in citing an article because of tendency to cite articles by famous authors, colleagues or critics should be taken into consideration. The important of 
self-citations should be acknowledged (Ale Ebrahim \& Salehi, 2013; Dumont, 1989). Moreover, name of some countries and organizations were missed and did not accessible in the Web of Science Website. The databases used for studying the social sciences and humanities have limitations (Garfield, 1982; Hammarfelt, 2011; Hellqvist, 2010; Linmans, 2010).

\section{Conclusions}

The current study might be considered as the first reportage on the most cited articles of art criticism. The findings represent that the articles written in English established mostly on art criticism and published in ISI journals are the most probable articles to be cited in the art field. The 11 top cited articles had qualitative method. The results indicate that the citation rate does not certainly conclude the impact or importance of a particular publication.

\section{References}

Albert, D. M. (1988). Analysis of the Archives' most frequently cited articles. Archives of Ophthalmology, 106(4), 465-470. http://dx.doi.org/10.1001/archopht.1988.01060130511026

Ale Ebrahim, N. (2014). Citation Frequency and Ethical Issue. Electronic Physician, 6(2), 814-815.

Ale Ebrahim, N., \& Salehi, H. (2013). Maximize Visibility: A Way to Increase Citation Frequency. International Education Studies, 6(11), 93-99.

Ale Ebrahim, N., Salehi, H., Embi, M. A., Habibi, F., Gholizadeh, H., \& Motahar, S. M. (2014). Visibility and citation impact. International Education Studies, 7(4), 120-125. http://dx.doi.org/10.5539/ies. v7n4p120

Ale Ebrahim, N., Salehi, H., Embi, M. A., Habibi, F., Gholizadeh, H., Motahar, S. M., \& Ordi, A. (2013). Effective strategies for increasing citation frequency. International Education Studies, 6(11), 93-99. http://dx.doi.org/10.5539/ies.v6n11p93

Archambault, É., Vignola-Gagne, É., Côté, G., Larivi? re, V., \& Gingrasb, Y. (2006). Benchmarking scientific output in the social sciences and humanities: The limits of existing databases. Scientometrics, 68(3), 329-342. http://dx.doi.org/10.1007/s11192-006-0115-z

Baltussen, A., \& Kindler, C. H. (2004). Citation classics in anesthetic journals. Anesthesia \& Analgesia, 98(2), 443-451. http://dx.doi.org/10.1213/01.ANE.0000096185.13474.0A

Bohannon, R. W., \& Roberts, D. (1991). Core journals of rehabilitation: identification through index analysis. International Journal of Rehabilitation Research, 14(4), 333-336. http://dx.doi.org/10.1097/ 00004356-199112000-00006

Cromer, J. (1990). History, Theory, and Practice of Art Criticism in Art Education. Point of View Series, National Art Education Association, 1916 Association Drive, Reston, VA 22019-1590.

Dubin, D., Hafner, A. W., \& Arndt, K. A. (1993). Citation classics in clinical dermatologic journals: citation analysis, biomedical journals, and landmark articles, 1945-1990. Archives of Dermatology, 129(9), 1121-1129. http://dx.doi.org/10.1001/archderm.1993.01680300049007

Dumont, J. E. (1989). The bias of citations. Trends in Biochemical Sciences, 14(8), 327-328. http://dx.doi. org/10.1016/0968-0004(89)90164-3

Earle, P., \& Vickery, B. (1969). Social science literature use in the UK as indicated by citations. Journal of Documentation, 25(2), 123-141. http://dx.doi.org/10.1108/eb026468

Elkins, J., \& Engelke, M. (2003). What happened to art criticism? Prickly Paradigm Press.

Garfield, E. (1982). Data from Arts and Humanities Citation Index Reveal the Interrelationships of Science and Humanities. Current Contents, 46, 5-7.

Garfield, E. (2006). The history and meaning of the journal impact factor. Jama, 295(1), 90-93. http://dx. doi.org/10.1001/jama.295.1.90

Glänzel, W. (1996). A bibliometric approach to social sciences. National research performances in 6 selected social science areas, 1990-1992. Scientometrics, 35(3), 291-307. http://dx.doi.org/10. 1007/BF02016902

Hall, G. (1998). BJA citation classics 1945-1992. British Journal of Anaesthesia, 80(1), 4-6. http://dx.doi. org $/ 10.1093 / \mathrm{bja} / 80.1 .4$

Hammarfelt, B. (2011). Interdisciplinarity and the intellectual base of literature studies: Citation analysis of highly cited monographs. Scientometrics, 86(3), 705-725. http://dx.doi.org/10.1007/s11192-010- 0314-5 
Hellqvist, B. (2010). Referencing in the humanities and its implications for citation analysis. Journal of the American Society for Information Science and Technology, 61(2), 310-318.

Hennessey, K., Afshar, K., \& MacNeily, A. E. (2009). The top 100 cited articles in urology. Canadian Urological Association Journal, 3(4), 293.

Hicks, D. (1999). The difficulty of achieving full coverage of international social science literature and the bibliometric consequences. Scientometrics, 44(2), 193-215. http://dx.doi.org/10.1007/BF02457380

Hicks, D., \& Wang, J. (2009). Towards a bibliometric database for the social sciences and humanities.

Jacso, P. (2005). As we may search-Comparison of major features of the Web of Science, Scopus, and Google Scholar citation-based and citation-enhanced databases. Current Science-Bangalore, 89(9), 1537.

Lankford, E. L. (1984). A phenomenological methodology for art criticism. Studies in Art Education, 25(93), 151-158. http://dx.doi.org/10.2307/1320696

Leydesdorff, L., \& Salah, A. A. A. (2010). Maps on the basis of the Arts \& Humanities Citation Index: The journals Leonardo and Art Journal versus "digital humanities" as a topic. Journal of the American Society for Information Science and Technology, 61(4), 787-801.

Leydesdorff, L., Hammarfelt, B., \& Salah, A. (2011). The structure of the Arts \& Humanities Citation Index: A mapping on the basis of aggregated citations among 1,157 Journals. Journal of the American Society for Information Science and Technology, 62(12), 2414-2426. http://dx.doi.org/10.1002/asi.21636

Line, M. B. (1999). Social science information: The poor relation. Inspel, 33(3), 131-136.

Linmans, A. J. (2010). Why with bibliometrics the humanities does not need to be the weakest link. Scientometrics, 83(2), 337-354. http://dx.doi.org/10.1007/s11192-009-0088-9

Loonen, M. P., Hage, J. J., \& Kon, M. (2008). Plastic surgery classics: characteristics of 50 top-cited articles in four plastic surgery journals since 1946. Plastic and Reconstructive Surgery, 121(5), 320e-327e. http://dx.doi.org/10.1097/PRS.0b013e31816b13a9

Nederhof, A. J., Zwaan, R. A., De Bruin, R. E. a., \& Dekker, P. J. (1989). Assessing the Usefulness of Bibliometric Indicators for the Humanities and the Social Sciences: A Comparative Study. Scientometrics, 15(5-6), 423-435. http://dx.doi.org/10.1007/BF02017063

Nederhof, A. J., Zwaan, R. A., De Bruin, R. E., \& Dekker, P. (1989). Assessing the usefulness of bibliometric indicators for the humanities and the social and beha vioural sciences: A comparative study. Scientometrics, 15(5), 423-435. http://dx.doi.org/10.1007/BF02017063

Nwagwu, W., \& Egbon, O. (2011). Bibliometric analysis of Nigeria's social science and arts and humanities publications in Thomson Scientific databases. The Electronic Library, 29(4), 438-456. http://dx.doi. org/10.1108/02640471111156722

Paladugu, R., Schein, M., Gardezi, S., \& Wise, L. (2002). One hundred citation classics in general surgical journals. World Journal of Surgery, 26(9), 1099-1105. http://dx.doi.org/10.1007/s00268-002-6376-7

Pikić, A., Mayer, M., \& Macan, B. (2012). (Inter) National Orientation of Croatian Social Sciences and Arts and Humanities Journals Indexed in the Web of Science Database. Društvena Istraživanja-Časopis za Opća Društvena Pitanja, (2), 505-521.

Ponce, F. A., \& Lozano, A. M. (2010). Highly cited works in neurosurgery. Part I: the 100 top-cited papers in neurosurgical journals: A review. Journal of Neurosurgery, 112(2), 223-232. http://dx.doi.org/10. 3171/2009.12.JNS091599

Portney, L., \& Watkins, M. ( 1993). Foundations of clinical research: applications to practice. Appleton \& Lange, East Norwalk, 148.

Risatti, H. (1987). Art criticism in discipline-based art education. Journal of Aesthetic Education, 21(2), 217-225. http://dx.doi.org/10.2307/3332751

Webster, B. M. (1998). Polish Sociology Citation Index as an example of usage of national citation indexes in scientometric analysis of social sciences. Journal of Information Science, 24(1), 19-32. http://dx.doi. org/10.1177/0165551984232009

Winclawska, B. M. (1996). Polish Sociology Citation Index (Principles for creation and the first results). Scientometrics, 35(3), 387-391. http://dx.doi.org/10.1007/BF02016909 


\section{Copyrights}

Copyright for this article is retained by the author(s), with first publication rights granted to the journal.

This is an open-access article distributed under the terms and conditions of the Creative Commons Attribution license (http://creativecommons.org/licenses/by/3.0/). 